\title{
Natural Products: A Potential Source of Malaria Transmission Blocking Drugs?
}

\author{
Phanankosi Moyo ${ }^{1, *}$, Grace Mugumbate ${ }^{2}$, Jacobus N. Eloff ${ }^{3}\left(\mathbb{D}\right.$, Abraham I. Louw ${ }^{1}{ }^{1}$, \\ Vinesh J. Maharaj ${ }^{4}$ and Lyn-Marié Birkholtz ${ }^{1, * \mathbb{B}}$ \\ 1 Malaria Parasite Molecular Laboratory, Department of Biochemistry, Genetics and Microbiology, Institute for \\ Sustainable Malaria Control, Faculty of Natural and Agricultural Sciences, University of Pretoria, Private \\ Bag x20, Hatfield, 0028 Pretoria, South Africa; braam.louw@up.ac.za \\ 2 Department of Chemistry, School of Natural Sciences and Mathematics, Chinhoyi University of Technology, \\ Private Bag, 7724 Chinhoyi, Zimbabwe; gmugumbate@cut.ac.zw \\ 3 Phytomedicine Programme, Department of Paraclinical Sciences, Faculty of Veterinary Science, University of \\ Pretoria, Private Bag x04, Onderstepoort 0110 Pretoria, South Africa; kobus.eloff@up.ac.za \\ 4 Department of Chemistry, Faculty of Natural and Agricultural Sciences, University of Pretoria, Private Bag \\ x20, Hatfield, 0028 Pretoria, South Africa; vinesh.maharaj@up.ac.za \\ * Correspondence: phanankosimoyo@gmail.com (P.M.); lbirkholtz@up.ac.za (L.-M.B.)
}

Received: 19 August 2020; Accepted: 16 September 2020; Published: 17 September 2020

\begin{abstract}
The ability to block human-to-mosquito and mosquito-to-human transmission of Plasmodium parasites is fundamental to accomplish the ambitious goal of malaria elimination. The WHO currently recommends only primaquine as a transmission-blocking drug but its use is severely restricted by toxicity in some populations. New, safe and clinically effective transmission-blocking drugs therefore need to be discovered. While natural products have been extensively investigated for the development of chemotherapeutic antimalarial agents, their potential use as transmission-blocking drugs is comparatively poorly explored. Here, we provide a comprehensive summary of the activities of natural products (and their derivatives) of plant and microbial origins against sexual stages of Plasmodium parasites and the Anopheles mosquito vector. We identify the prevailing challenges and opportunities and suggest how these can be mitigated and/or exploited in an endeavor to expedite transmission-blocking drug discovery efforts from natural products.
\end{abstract}

Keywords: transmission blocking; Plasmodium; Anopheles; natural products; extracts; malaria; gametocytes; gametes; ookinete; oocyst; endectocide

\section{Introduction}

\subsection{Transmission-Blocking: An Integral Tool for Malaria Elimination}

In spite of the many efforts that have been explored to control malaria, the disease still remains a global health threat [1-3]. The intricate multistage life cycle of the malaria-causing Plasmodium parasite, which spans both development in the human host and mosquito vector, has been one of the major reasons for its survival and continued infection of humans. Each developmental stage of the parasite is characterised by distinct biological processes that causes the variation in stage-specific drug susceptibility [4-9]. After hepatic schizogony (liver stage development as initial step after infection with sporozoites transmitted by a feeding female Anopheles mosquito), pathology is associated with asexual intra-erythrocytic development of the parasite, typified by progression from ring to trophozoites before schizogony occurs to release daughter merozoites able to infect new erythrocytes and continue proliferation. Sexual development relies on gametocytogenesis of a small fraction of the parasites ( $1 \%$ of the population) and is characterised by the parasite differentiating through five 
developmental stages (stages I-V) in the human host to produce mature gametocytes (stage V) able to be transmitted by a feeding mosquito. Once back in the mosquito vector, gamete formation ensues followed by fertilisation and finally oocyst formation before sporogony [10].

For decades, antimalarial drug development efforts have been (rightly so) skewed towards the discovery of chemotherapeutic agents, drugs able to target the symptomatic intra-erythrocytic asexual stage Plasmodium parasites and cure a patient of disease and preventing mortality [11,12]. However, this does not eliminate carriage of gametocytes in these patients and indeed, parasite transmission largely continues unabated due to the general inactivity of these drugs against the sexual stages of the Plasmodium parasite life cycle. As global malaria programs shift from control to elimination and eradication [13], emphasis has therefore been placed on discovery of additional activities associated with new antimalarial candidates. Not only should such candidates be able to kill asexual parasites and therefore be useful therapeutically, but they should also have transmission-blocking activity, targeting either sexual stages of Plasmodium parasites (classified by the Medicines for Malaria Venture as target candidate profile 5, TCP-5, $[10,14,15]$ ) or the Anopheles mosquito vector (endectocides, TCP-6, $[10,16]$ ).

It is anticipated that transmission-blocking drugs will reduce the burden of malaria by substantially decreasing the number of infectious mosquitoes, resulting in significant decline in secondary human infections [14]. In fact, interruption of transmission through vector control targeted interventions, has been at the heart of some of the major success stories in the fight against malaria including elimination of the disease in several countries [17]. However, the efficacy of vector control has plateaued and is undermined by, amongst others, outdoor feeding behaviour of mosquitoes and insecticide resistance [18]. The use of drugs to target the parasite and thereby prevent transmission is therefore an enticing new possibility as add-on to current standard practice. Moreover, the low number of sexual stage parasites marks them for targeting and their non-proliferative nature could decrease the probability of development of resistance to transmission-blocking drugs [19], a fact compromising the use of all antimalarial chemotherapeuticals targeting asexual stages.

Despite these advantages and the growing body of empirical and clinical evidence substantiating its usefulness [20-23], there is currently only one WHO approved transmission-blocking drug, primaquine. Unfortunately, its use is limited due to toxicity concerns [24] and it cannot be prescribed to pregnant women, breast feeding mothers and infants [25], populations that has a large potential parasite reservoir, which will perpetuate parasite transmission. It is thus imperative to discover new, safe and clinically effective transmission-blocking agents.

\subsection{Can Natural Products Prove a Panacea for Transmission-Blocking Drug Discovery Efforts?}

Natural products are an extensive reservoir of diverse chemical compounds with novel biological targets and mode-of-action (MoA). These qualities have made them a significant component of the global pharmaceutical arsenal with over half of currently commercially available medicinal drugs having been either derived from a natural source or been inspired by natural compounds [26,27]. The malaria field has equally benefitted, with natural products having played a pivotal role in the discovery of chemotherapeutic antimalarial agents with two mainstay malaria chemotherapeutic agents, artemisinin and quinine, both derived from medicinal plants [28,29]. These agents also served as scaffolds for the synthesis of derivatives including artemether, dihydroartemisinin, artesunate, chloroquine and mefloquine. Another antimalarial, atovaquone, also traces its discovery to a plant-derived natural compound [28]. Natural compounds isolated from microorganisms have similarly had a profound impact towards discovery of chemotherapeutic antimalarial agents by providing privileged scaffolds for the synthesis of derivatives including the tetracycline, doxycycline and the lincosamide, clindamycin $[30,31]$.

However, research on natural products as a source of drugs drastically declined towards the end of the 20th century [32]. This was attributed to challenges associated with downstream development of such compounds in medicinal chemistry programmes, particularly due to limited availability of starting material and structural complexity of purified natural product compounds that restricts 
their synthesis. Further compounding factors include frequent isolation of pan-assay interfering compounds, repeated isolation of known molecules and the non-compatibility of some secondary metabolites with high-throughput screening platforms [32]. Despite this, the emergence of drug resistant microorganisms and limited chemical structural diversity of synthetic libraries has led to a revival of interest in natural products as sources for drug discovery [33]. The recent discovery of structurally unique bacterial-derived antibiotics, teixobactin [34] and darobactin [35] and a anticancer marine alkaloid, trabectedin [36] is fuelling new research. Likewise, malaria research has benefited from this renaissance with the discovery and development of the natural product inspired clinical antimalarial candidates cipargamin [37] and artefenomel [38]. Apart from providing leads, natural products are also opening up new avenues for rational drug discovery efforts through the identification of useful novel biological targets and pathways in Plasmodium parasites [39].

Accumulating evidence supports natural products as a source for transmission-blocking drugs targeting the sexual stages of Plasmodium parasites and / or the Anopheles mosquito. Some natural compounds exhibit a TCP-5 activity profile while others have dual activity with additional potency against asexual parasites (defined with both TCP-1 and TCP-5 activity). The low hit rates of the synthetic compounds against sexual stage Plasmodium parasites [40-43], motivates expansion of the search for transmission-blocking drugs to natural products. This is justified particularly since their diverse chemical space and wide range of pharmacophores could lead to identification of novel lead compounds and associated targets in the parasite and as such avert existing drug resistance challenges. We therefore discuss here the status quo of natural products that have been explored for transmission-blocking activity in Plasmodium parasites and debate future usefulness of natural products and provide guidance as to standardised strategies to explore this rich source more expeditiously and economically to discover new transmission-blocking hits.

Transmission-blocking screens are typically complex since compounds should show activity primarily against gametocytes in humans, but also has to translate to retained activity against early sporogonic stages (ESS, gametes and/or ookinetes) and oocyst mosquito stages (Figure 1a). Alternatively, compounds active against the Anopheles mosquito itself can then be used in the form of endectocides $[10,40]$. Moreover, the assays used in transmission-blocking screens are technically challenging as they involve multiple biological assay platforms that spans the entire transmission-blocking cascade, with the standard membrane feeding assay (SMFA) serving as the gold standard assay to confirm a block in human-to-mosquito transmission [40]. Until now, transmission-blocking screens for natural products have been largely confined to late-stage gametocytes (stage IV/V gametocytes) whilst screens directly against gametes or oocysts or for identification of endectocides have received the least attention (Figure 1a).

A summary of the current profile of natural compounds that have been screened for transmission-blocking antimalarial potential, revealed that 80 pure natural product compounds (and 11 derivatives generated from some of these pure compounds) have been investigated for some form of transmission-blocking activity. Of this, 21 compounds are from microbial origin and 59 from plants (Figure 1a, Table S1). In addition to these purified compounds, complex and/or minimal extracts from 37 plant species and 10 herbal products have been associated with at least some transmission-blocking activity. The plant species investigated were drawn from 17 different plant families with Asteraceae, Meliaceae and Combretaceae being the most represented (Figure 1b). 


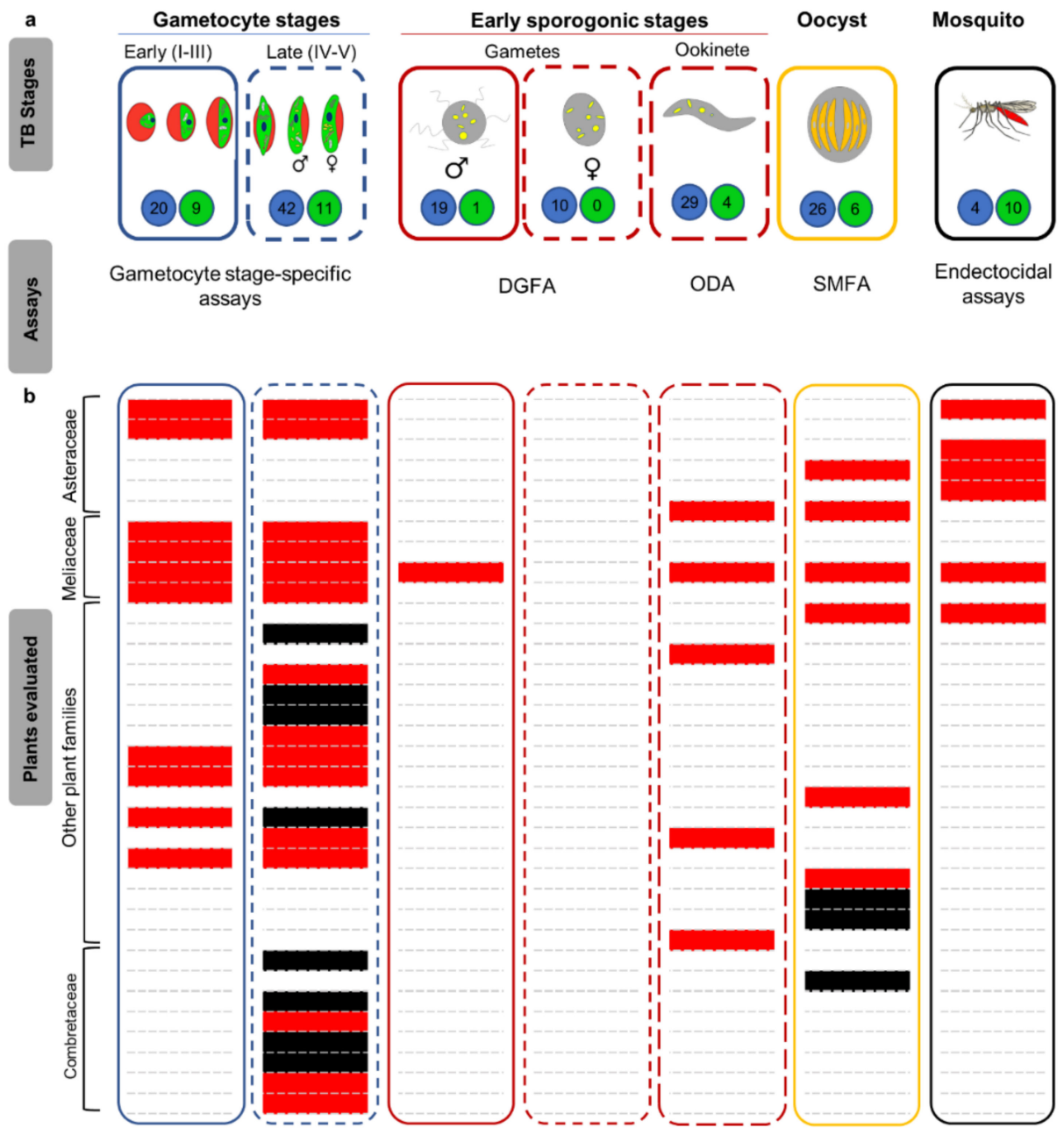

Figure 1. Overview of transmission-blocking assays and natural product origins. (a) Sexual stages within the human host are categorised into early-stage (I-III) and late-stage (IV-V) gametocytes. Gametocytes are sexually dimorphic with both male (micro-) and female (macro-) gametocytes found in human host at a ratio of $\sim 1: 3.6$, respectively. Inside the mosquitoes' midgut, micro-gametocytes develop into mature micro-gametes, a process called exflagellation. Each micro-gametocyte produces eight micro-gametes while a macro-gametocyte matures into a single macro-gamete. Gametocyte development into gametes is termed gametogenesis. Micro- and macro-gametes fuse together to form a zygote that develops into a motile ookinete. Gamete-zygote-ookinete development constitute early sporogonic stages (ESS). Ookinetes penetrate the midgut wall where they form oocysts which enlarge over time and eventually rupture to release sporozoites. Different assay platforms to assess the activity against different stages include gametocyte stage specific assays (which assess either development, viability, metabolic or redox status), dual gamete formation assays (DGFA) (examine development of mature gametocytes into either micro- or macro-gametes), ookinete development assay (ODA) (examines development of gametes to ookinetes), standard membrane feeding assay (SMFA, assess either the number of oocysts per mosquito (termed oocyst intensity) or total number of mosquitoes with oocysts (termed oocysts prevalence) and endectocidal assays (which examine insecticidal properties of drugs upon ingestion by mosquito). Numbers indicated in blue and green circles indicate number of pure natural compounds and plant extracts screened per each respective stage. TB-transmission-blocking. (b) Summary of plant species reviewed for activity against transmission-blocking stages. Quite noticeable is the lack of investigations on gametes. It is also evident that the Asteraceae, Meliaceae and Combretaceae are the most investigated plant families with most species from the latter family being inactive against the respective transmission-blocking stages they were interrogated against. The colour scale indicates active (red) and inactive (black) plants species against specific stages. 


\section{Effectiveness of Natural Products Against Transmission-Blocking Stages}

\subsection{Microbial-Derived Natural Products}

\subsubsection{Ionophores}

Ionophores are lipid-soluble carboxylic polyether complexes that facilitate the transportation of ions across cellular membranes [44]. Inspired by the drug repurposing efforts, D'Alessandro et al. [45] screened three ionophores, salinomycin, nigericin and monensin (all originally isolated from different Streptomyces sp. [46]), against early- and late-stage $P$. falciparum gametocytes in vitro.

All three compounds were highly active $\left(\mathrm{IC}_{50}<200 \mathrm{nM}\right.$, Figure 2, Table 1$)$ against both gametocyte stages, with salinomycin showing preference to late-stage gametocytes [45]. The ionophores were able to inhibit development of $P$. berghei gametocytes into early sporogonic stages (ESS) in vitro and the transmission-blocking properties of these compounds was confirmed in vivo using the standard membrane feeding assay (SMFA) (Table 1) [45]. Maduramicin, an ionophore produced by the actinomycete Actinomadura rubra, [47] has transmission-blocking properties both in vitro and in vivo [48,49], killing late-stage P. falciparum gametocytes $\left(\mathrm{IC}_{50}<200 \mathrm{nM}\right.$ ) (Figure 2, Table 1). This ionophore is fast acting, reducing late-stage gametocyte viability by $>90 \% 12 \mathrm{~h}$ post treatment, with morphological changes evident even $1 \mathrm{~h}$ after drug exposure. This is similarly reflected in in vivo transmission-blocking activity where oocyst development was significantly blocked by maduramicin following exposure of gametocytes to drug for only 90 min prior to mosquito feed [48].

\subsubsection{Peptides, Glycosides and Miscellaneous}

The proteasome inhibitor, epoxomicin, is one of the most widely investigated peptides routinely used for transmission-blocking as a reference drug for in vitro gametocytocidal assays [48,50-54]. It has potent $\left(\mathrm{IC}_{50}<10 \mathrm{nM}\right.$, Figure 2, Table 1$)$ in vitro activity against late-stage $P$. falciparum gametocytes [50,51,53,54], with sex-specific preference towards P. falciparum micro-gametes in vitro [50,55]. In vivo, epoxomicin completely blocks the formation of P. falciparum oocysts in An. stephensi [55]. The peptide carmaphycin B targets the $\beta 5$ subunit of the yeast 20s proteasome, a well characterised antimalarial target [56]. Carmaphycin $B$ is potent $\left(\mathrm{IC}_{50}<1 \mu \mathrm{M}\right)$ against both intra-erythrocytic asexual P. falciparum parasites and gametocytes, with 40-fold preference towards asexual parasites (Figure 2, Table 1) [57]. Toxicity concerns with this compound resulted in norleucine replacement of the methionine moiety and racemic changes on valine, drastically improving selectivity of a new derivative [57].

Cyclic oligopeptides have been explored including the antibiotic thiostrepton, which is moderately active against intra-erythrocytic asexual $P$. falciparum parasites $\left(\mathrm{IC}_{50}=8.9 \mu \mathrm{M}\right)$ with a dual MoA: blocking protein translation in the apicoplast and inhibiting the 20s proteasome of the parasite [58]. Thiostrepton is similarly only moderately potent against the five development stages of gametocytes ( $\mathrm{IC}_{50}$ ranging from 1.82 to $3.4 \mu \mathrm{M}$ ) [4], but has a 14-fold enhanced activity against micro-gametes compared to macro-gametes (Figure 2, Table 1) [9]. This compound significantly reduces $P$. berghei oocyst development in An. stephensi mosquito midguts as well as reducing the number of sporozoites per mosquito [59]. Dactinomycin (a known transcription inhibitor in eukaryotic cells) and romidepsin (histone deacetylase inhibitor) [49] both show sub-micromolar gametocytocidal activity (Figure 2, Table 1), with in vivo transmission-blocking activity only confirmed for romidepsin [60]. Although these oligopeptides do show potency, their large MW and poor solubility detracts from their development as TCP-5 candidates. 


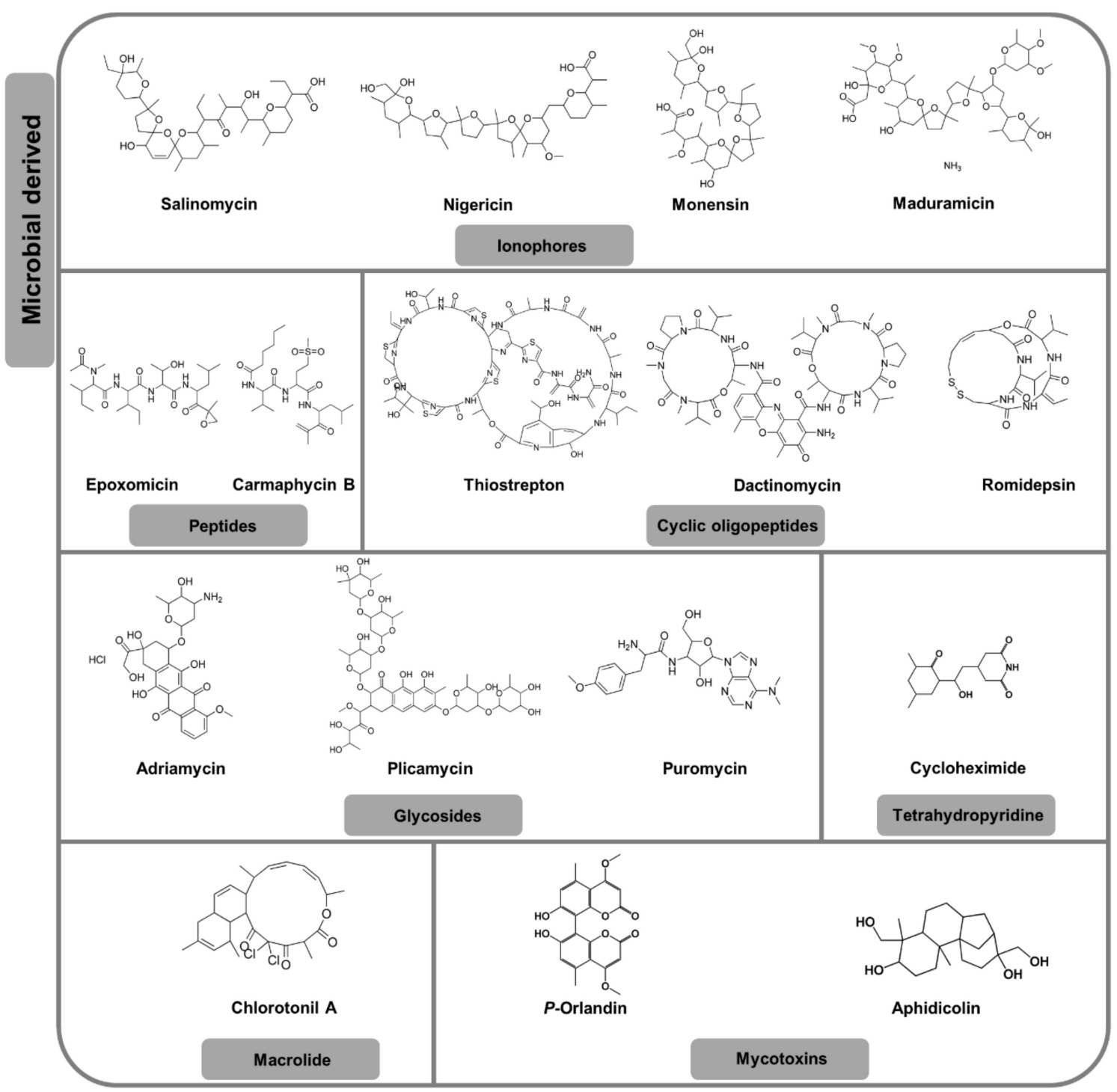

Figure 2. Chemical structures of highly potent microbial-derived compounds targeting $P$. falciparum transmissible stages.

The glycosides adriamycin (a DNA synthesis inhibitor) and plicamycin (a RNA synthesis inhibitor) [49] similarly show sub-micromolar gametocytocidal activity (Figure 2, Table 1), indicating that inhibitors of essential nucleotide synthesis processes are affective against the transmissible forms of the parasite. This extends to transcription inhibitors such as puromycin [4,6,7], with equipotent in vitro activity against all five development stages of $P$. falciparum gametocytes [4]. This compound additionally has the advantage of being fast acting against $P$. falciparum macro-gametes $(<1 \mathrm{~h})$ [50]. Similarly, the antibiotic cycloheximide has an almost exactly similar profile to puromycin, killing all P. falciparum gametocyte stages, and being fast acting against macro-gametes [50], whilst also blocking P. berghei ookinetes development (Figure 2, Table 1) [61].

The macrolide chlorotonil A is highly potent against late-stage gametocytes (Figure 2, Table 1) [62]. Despite a plethora of investigations examining their transmission-blocking potential, the antibiotics tetracycline, fosmidomycin and deferoxamine have consistently proved to be inactive against both P. falciparum gametocytes ( $\mathrm{IC}_{50}$ values $>12.5 \mu \mathrm{M}$ ) and macro-gametes with the latter two compounds additionally unable to block $P$. berghei ookinete development in vitro [4,50,61]. All three compounds failed to significantly reduce the development of $P$. falciparum parasites into oocysts in mosquito vector (Table S1) [63]. 
Preliminary assessment of two usnic acid derivatives, designated BT37 and BT122, showed them to be potent in vivo (both had $>99 \%$ inhibition of oocyst formation at $250 \mu \mathrm{g} / \mathrm{mL}$ ) [64]. Dose-response studies for inhibition of oocyst formation were estimated using logistic regression to range from 35 to $234 \mu \mathrm{M}$ for both derivatives [64]. While both these derivatives were incapable of blocking exflagellation of mature micro-gametes, they did inhibit transformation of zygotes-ookinetes (Table S1) [64].

\subsubsection{Mycotoxins}

Fibrinogen-related protein 1 (FREP 1) is one of the many proteins that facilitate mosquito infection by Plasmodium parasites and thus transmission [65]. An in vitro screen of a library of crude fungal extracts for compounds that disrupt interaction of FREP 1 with Plasmodium parasites identified three active extracts, with that from Aspergillus niger (92\% inhibition of FREP 1-Plasmodium association) being the most potent [66]. P-orlandin was identified as the active principle from this extract and has in vivo transmission-blocking activity against oocysts (Figure 2, Table 1) [66]. Aphidicolin (a DNA synthesis inhibitor, mycotoxin from Cephalosporum aphidicola) $[67,68]$ is active by inhibiting exflagellation of P. falciparum micro-gametes [64], without displaying overt toxicity (Figure 2, Table 1).

Table 1. Transmission-blocking activity of microbial-derived natural product compounds. (Further details provided in Table S1).

\begin{tabular}{|c|c|c|c|c|c|c|c|c|c|}
\hline \multirow{2}{*}{ Compound } & \multirow{2}{*}{ MW } & \multirow{2}{*}{ cLogP } & \multicolumn{6}{|c|}{$\begin{array}{c}\text { Transmission-Blocking Stage Activity } \\
\left(\mathrm{IC}_{50}, \mu \mathrm{M} / \% \text { inhibition } @>5 \mu \mathrm{M}^{a} \text { or }<0.5 \mu \mathrm{M}^{b}\right)\end{array}$} & \multirow{2}{*}{ References } \\
\hline & & & EG & LG & Mic & Mac & ESS & Ooc & \\
\hline \multicolumn{10}{|l|}{ Ionophores } \\
\hline Salinomycin & 751 & 5 & 0.014 & 0.006 & & & 0.035 & $0.002^{c} ; 0.018^{d}$ & [45] \\
\hline Nigericin & 724 & 4.69 & 0.003 & 0.001 & & & & & [45] \\
\hline Monensin & 670 & 3.74 & 0.002 & 0.006 & & & 0.017 & $0.002^{c} ; 0.001^{d}$ & [45] \\
\hline Maduramicin & 934 & 1.47 & & 0.015 & & & & $100 \% e^{e}$ & {$[48,49]$} \\
\hline \multicolumn{10}{|c|}{ Peptides, glycosides and miscellaneous } \\
\hline Epoxomicin & 554 & 2.12 & $99.8 \% a$ & 0.0004 & Inactive & 0.008 & & $100 \% b$ & {$[48,50-54]$} \\
\hline Carmaphycin & 515 & 3.31 & & 0.160 & & & & & [57] \\
\hline Thiostrepton & 1664 & -1.04 & 2.8 & 1.8 & 0.096 & 1.4 & 8 & Active $^{a}$ & {$[4,9,59]$} \\
\hline Dactinomycin & 1255 & 0.6 & & 0.015 & & & & & [49] \\
\hline Romidepsin & 540 & 1.39 & & 0.637 & & & & Active $^{b}$ & {$[49,60]$} \\
\hline Adriamycin & 579 & 0.36 & & 0.526 & & & & & [49] \\
\hline Plicamycin & 1085 & 0.25 & & 0.833 & & & & & [49] \\
\hline Puromycin & 471 & -0.22 & 0.103 & 0.110 & & $100 \%^{a}$ & & & {$[4,6,7,50]$} \\
\hline Cycloheximide & 281 & 1.3 & 0.6 & 0.477 & & $100 \%{ }^{a}$ & $100 \%{ }^{a}$ & & {$[50,61]$} \\
\hline Chlorotonil A & 479 & 4.81 & & 0.030 & & & & & [62] \\
\hline \multicolumn{10}{|l|}{ Mycotoxins } \\
\hline P-Orlandin & 410 & 3.18 & & & & & & $56.7 \%{ }^{a} ; 35.3 \%{ }^{a}$ & [66] \\
\hline Aphidicolin & 338 & 2.39 & & & $100 \%^{b}$ & & & & [64] \\
\hline
\end{tabular}

\subsection{Plant-Derived Natural Products}

\subsubsection{Terpenes and Terpenoids}

Sesquiterpene lactones are emerging as a good starting point in search of transmission-blocking drugs with several studies proving their potential. The most widely investigated member of this class of compounds is artemisinin, along with its derivatives (Figure 3, Table 2). These agents have consistently been shown in vitro to be potent against early-stage $P$. falciparum gametocytes $[4,5,7]$ but their activity against late-stage gametocytes is rather ambiguous with conflicting data (in some instances $>100$-fold differences in $\mathrm{IC}_{50}$ values) $[4,6,7,51,70]$. Such discrepancies can be explained by variation in stage composition of parasite cultures and dissimilarities in sensitivity of the different assay platforms used [40]. Nonetheless, artemisinin sterilises mature micro-gametocytes and blocks 
macro-gamete development $[9,50]$. While artemisinin does not inhibit $P$. berghei ookinetes development in vitro, it blocks P. falciparum oocysts formation in Anopheles mosquito [63,71]. Clinical studies have shown artemisinin derivatives to reduce gametocyte density and carriage time [72,73]. However, artemisinin-based combination therapies (ACTs) are unable to clear off the transmittable mature stage V gametocytes clinically [74].

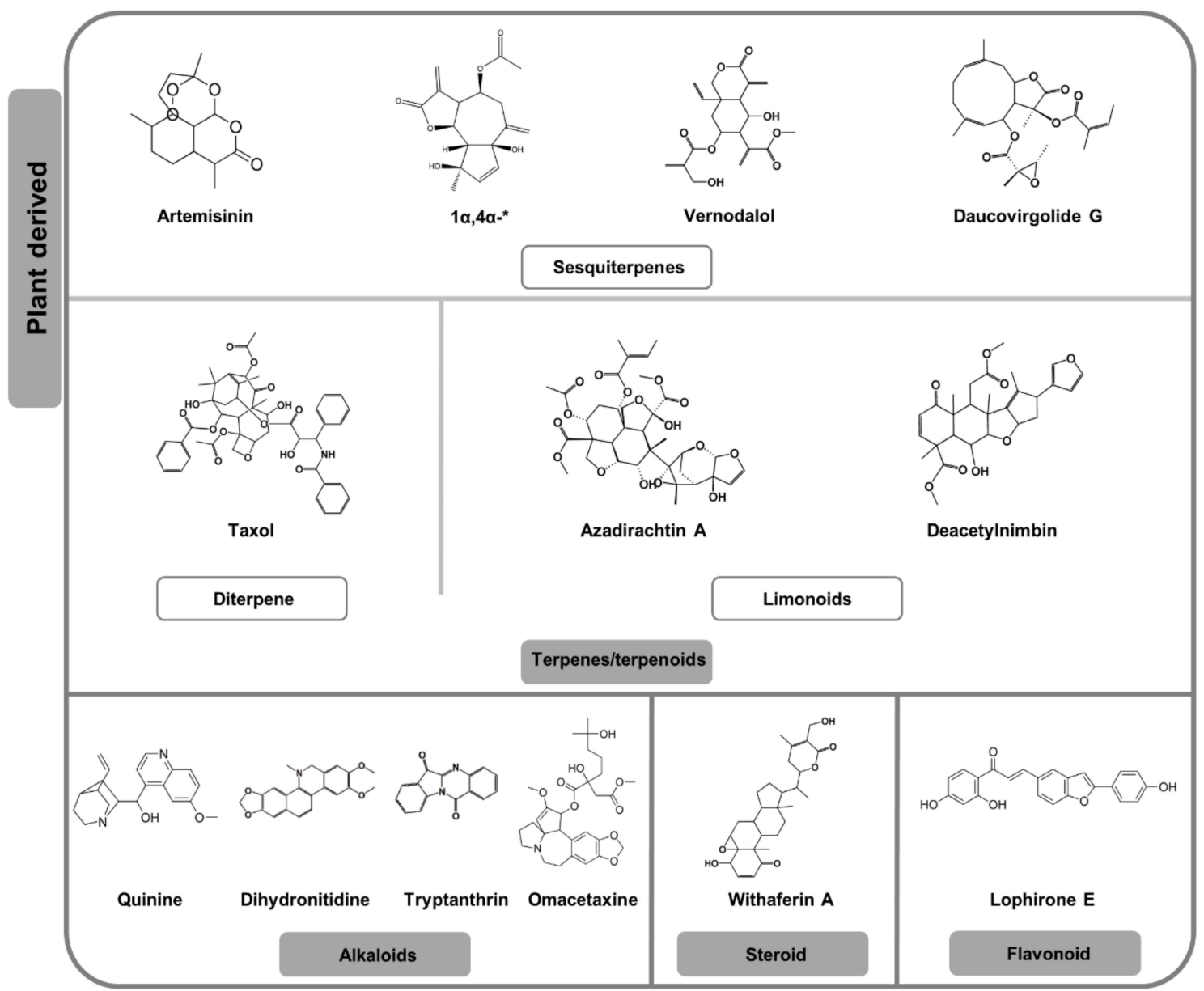

Figure 3. Chemical structures of selected plant-derived compounds with some described activity (including only moderate) against $P$. falciparum transmissible stages. ${ }^{*} 1 \alpha, 4 \alpha$-dihydroxybishopsolicepolide.

Additional sesquiterpene compounds have been investigated from plant species belonging to the Asteraceae family. Parthenin and parthenolide (from the Asteraceae family members Parthenium hysterophorus and Tanacetum parthenium, respectively), inhibit exflagellation of micro-gametes and block ookinete-oocysts development [75]. From another Asteraceae plant species, Artemisia afra, two previously undocumented gametocytocidal guaianolide sesquiterpene lactone compounds (1 $\alpha, 4 \alpha$-dihydroxybishopsolicepolide and yomogiartemin) were shown to have $\mu \mathrm{M}$ gametocytocidal activity, the former with a three-fold selectivity towards late-stage compared to early-stage gametocytes (Figure 3, Table 2, Table S1) [76]. From Vernonia amygdalina (Asteraceae), two sesquiterpene lactones were isolated, vernodalol and vernolide, with both showing only marginal ESS activity (Figure 3, Table 2, Table S1) [77]. A germacranolide sesquiterpene lactone from Daucus virgatus (Apiaceae), daucovirgolides $\mathrm{G}$, was the only compound with marked potency in vitro, strongly inhibiting ESS development (Figure 3, Table 2, Table S1) [78,79].

Taxol (a diterpene isolated from the plant Taxus brevifolia (Taxaceae) [80]) (Figure 3, Table 2, Table S1), that inhibit transformation of P. gallinaceum zygotes into ookinetes in vitro by targeting 
microtubules, within $6 \mathrm{~h}$ [81]. Furthermore, zygotes exposed to different dosages of these drugs for $4 \mathrm{~h}$ failed to develop into oocysts in midguts of Aedes aegypti mosquitoes [81].

Azadirachta indica (Meliaceae), the neem tree native to India where it has been used for $>3500$ years for malaria treatment, has been comprehensively studied for its transmission-blocking activity [82-89]. A. indica fractions are active in vitro against both early- and late-stage P. falciparum gametocytes $\left(\mathrm{IC}_{50}=0.001 \mu \mathrm{g} / \mathrm{mL}\right)[85,87]$. Transmission-blocking activity of $A$. indica has been conclusively demonstrated in vivo (by blocking $P$. berghei gametocyte-ESS development) and ex vivo (inhibiting $P$. falciparum gametocyte and oocyst development) [83,84]. The potency of $A$. indica against sexual stages of Plasmodium has been ascribed to limonoids (a class of terpenoids produced by the plant species), with azadirachtin A being the most prominent. Azadirachtin A, along with three of its synthetic derivatives (Table S1), are similarly potent against $P$. berghei micro-gametes $\left(\mathrm{IC}_{50}\right.$ ranging from 1.8 to $2.7 \mu \mathrm{M}$ ) (Figure 3, Table 2, Table S1) [82]. Structure-activity relationship analysis showed that the hemi-acetal moiety on carbon-11 to be critical for the observed pharmacological effect of these compounds. Azadirachtin A additionally inhibits exflagellation of gametes ex vivo and blocks development of ESS [88]. The MoA of azadirachtin A has been elucidated to be an impairment of microtubules formation during exflagellation [90]. In contrast to its potency against gametes, azadirachtin A is inactive against asexual Plasmodium parasites [90]. Another limonoid shown to have activity against ESS stages is deacetylnimbin [89]. Unlike azadirachtin A, deacetylnimbin has the advantage of being thermally and chemically stable [89]. This is an important property to consider in developing drugs targeting the ESS development process in the mosquito (contraceptive drugs) since they ought to have a long half-life equal to the peripheral circulation period of gametocytes which can be as long as 55 days $[89,91]$. Structural comparisons between deacetylnimbin, azadirachtin A and other A. indica compounds namely, nimbin (poorly active against ESS) and salannin (inactive against ESS), suggested that the presence of a free hydroxyl moiety was crucial for potency [89]. Gedunin, a limonoid highly active in vitro against asexual Plasmodium parasites, has been inferred to have an inhibitory effect on the development of oocysts in the mosquito vector while existing data suggests both azadirone and azadidarione to be incapable of blocking oocysts development (Table S1) [84].

\subsubsection{Alkaloids, Steroids and Miscellaneous}

The gametocytocidal activity of quinine has been a subject of investigation since the 1940s [92]. In some studies, quinine is reported to be more selectively potent towards early-stage $P$. falciparum gametocytes than to late-stage gametocytes (> 15-fold variation in $\mathrm{IC}_{50}$ values) (Figure 3, Table 2, Table S1) $[4,5,51]$, whilst other studies show a six-fold late-stage gametocytes preference $[7,49]$. Interestingly, quinine is reported to be active against $P$. vivax and $P$. malariae gametocytes [93]. While it has poor activity inhibiting development of P. falciparum macro-gametes [50] and is incapable of arresting $P$. berghei ookinete development in vitro [61], quinine is able to block $P$. falciparum oocyst development in vivo [63]. Other alkaloids including dihydronitidine and heitziquinone, isolated from the plant species Zanthoxylum heitzii (Rutaceae), also showed activity against ookinete development in vitro [94]. The quinazoline alkaloid, tryptanthrin and its synthetic derivatives designated NT1 and T8, have significant gametocytocidal activity in vitro (Figure 3, Table 2, Table S1) [95]. However, of the three agents only NT1 strongly inhibited exflagellation of micro-gametes (Table S1) [95]. Cryptolepine and a root extract of its parent plant, Cryptolepis sanguinolenta (Lindl.) Schlechter (Periplocaceae) both demonstrate moderate gametocytocidal activity [96]. The MoA of cryptolepine on asexual Plasmodium parasites has been deciphered to be partly due to inhibition of $\beta$-haematin formation [97], a non-viable late-stage gametocyte target [4]. Another alkaloid with demonstrated late-stage gametocyte activity is the protein translation inhibitor omacetaxine [49].

While steroids have this far received minimal attention within the malaria transmission-blocking drug discovery field, a few studies have provided interesting insights into their TCP- 5 credentials. Withaferin A (a transcription inhibitor) is one such compound being highly potent against late-stage gametocytes (Figure 3, Table 2) [49]. Three steroids, designated SN-1, SN-2 and SN-4, isolated 
from the plant, Solanum nudum Dunal (Solanaceae), were assessed against ex vivo P. vivax parasites. Only compounds SN-1 and SN-2 significantly reduced infectivity [98], although this could not be discerned from solubilising agents included such as polyvinylpyrrolidone (PVP). Encouragingly, SN-2 further significantly reduced oocyst density, a phenotypical effect not observed for PVP (Table S1) [98]. The results from this study are important as they do point to natural products being useful in targeting sporogonic stages of P. vivax. In a recent study, a derivative of the steroid sarachine, designated 1o, was demonstrated to be active against early, mid and late-stage P. falciparum gametocytes as well as in blocking P. berghei oocysts development in vivo (Table S1) [99].

Additional screens for transmission-blocking activity associated with plant extracts include a screen of extracts from 12 plant species against late-stage gametocytes of $P$. falciparum in vitro with only extracts of five species, Terminalia macroptera (Combretaceae), Combretum collinum (Combretaceae), Argenome mexicana (Papaveraceae), Zanthoxylum zanthoxylö̈des (Rutaceae) and Lophira lanceolate (Ochnaceae) [100]. Most extracts had moderate activity $\left(\mathrm{IC}_{50}\right.$ ranging from 20.6 to $54.7 \mu \mathrm{g} / \mathrm{mL}$ ) with only the stem bark ethanol extract of $L$. lanceolate demonstrating good activity $\left(\mathrm{IC}_{50}=11.4 \mu \mathrm{g} / \mathrm{mL}\right)$ [100]. A bioassay-guided approach led to the isolation of seven biflavonoid compounds from L. lanceolate including lophirone $\mathrm{E}$ which was 100-fold more active towards late-stage gametocytes compared to asexual stage P. falciparum parasites (Figure 3, Table 2) [101]. Interestingly, screening L. lanceolate extracts against ESS led the isolation of a different set of compounds, (glucolophirone C, and the lanceolins A and B, IC 50 values ranging from $10.95 \mu \mathrm{M}$ to $113.58 \mu \mathrm{M}$ ), indicating stage-specific activities (Table S1) [102].

Paton et al. [103] recently demonstrated that exposure of female Anopheles mosquitoes to relatively low concentrations of atovaquone (an analogue of a plant-derived natural compound which targets cytochrome $b$ ) shortly after P. falciparum infection rapidly blocked zygote-ookinete development inside the mosquitoes midgut. This consequently led to failure of oocysts development, rendering the mosquitoes non-infective (Table S1) [103]. Atovaquone could be administered in a way that mimicked contact with an insecticide on a bed net. Its lipophilic nature allowed for its rapid absorption via the mosquito's legs and into the midgut where it exerted its sporogonic effect. The study opens up new, previously unexplored avenues which, if properly exploited, may have a profound effect on malaria transmission contributing immensely towards the elimination and eradication solution.

Table 2. Transmission-blocking activity of plant-derived natural product compounds. (Further details provided in Table S1).

\begin{tabular}{|c|c|c|c|c|c|c|c|c|c|}
\hline \multirow[t]{2}{*}{ Compound } & \multirow[t]{2}{*}{ MW } & \multirow[t]{2}{*}{$\operatorname{cLog} P$} & \multicolumn{6}{|c|}{$\begin{array}{l}\text { Transmission-Blocking Stage Activity } \\
\left(\mathrm{IC}_{50}, \mu \mathrm{M} / \% \text { inhibition } @>5 \mu \mathrm{M}^{a}\right)\end{array}$} & \multirow[t]{2}{*}{ References } \\
\hline & & & EG & LG & Mic & Mac & ESS & Ooc & \\
\hline Artemisinin & 282 & 2.5 & 0.012 & 0.037 & 0.224 & 0.120 & Inactive & $93 \% a$ & {$[4,6,7,9,50,51,63,70,71]$} \\
\hline $1 \alpha, 4 \alpha-^{*}$ & 320 & 0.97 & 17.5 & 6.3 & & & & & [76] \\
\hline Vernodalol & 392 & 1.45 & & & & & 18.7 & & [77] \\
\hline Taxol & 853 & 3.39 & & & & & $\sim 80 \% a$ & & [81] \\
\hline Azadirachtin A & 720 & 1.08 & & & 3.5 & & 17.2 & & {$[82,88]$} \\
\hline Deacetylnimbin & 498 & 2.77 & & & & & 6 to 25 & & [89] \\
\hline \multicolumn{10}{|c|}{ Alkaloids, Steroids and Miscellaneous } \\
\hline Quinine & 324 & 2.81 & 0.44 & 0.318 & & $29 \%^{a}$ & $22.6 \%{ }^{a}$ & $85 \%{ }^{a}$ & {$[4,5,7,49-51,61,63]$} \\
\hline Lophirone E & 372 & 3.95 & & 0.14 & & & & & [101] \\
\hline
\end{tabular}

${ }^{a} \%$ inhibition at $5 \mu \mathrm{M} ;{ }^{b}$ ESS development; ${ }^{c}$ Zygote-ookinete development, ${ }^{d} \%$ Inhibition of development at concentration equal to $\mathrm{IC}_{90}$ value against asexual stages; ${ }^{*} 1 \alpha, 4 \alpha$-dihydroxybishopsolicepolide. MW and cLogP calculated using SwissADME online suite [69]. EG-early-stage gametocytes; LG-late-stage gametocytes; Mic-micro-gametes; Mac-macro-gametes; ESS-early sporogonic stages; Ooc-oocysts. 


\subsection{Herbal Remedies as Gametocytocidal Agents}

Ten herbal products used for malaria treatment in Ghana showed activity (at $100 \mu \mathrm{g} / \mathrm{mL}$ ) in vitro against both early and late-stage $P$. falciparum gametocytes. Interestingly, at $1 \mu \mathrm{g} / \mathrm{mL}$, the herbal product $\mathrm{YF}$, was significantly more potent against late-stage gametocytes in comparison to early-stage gametocytes, whereas herbal product $\mathrm{RT}$ used at sub-optimal concentrations ( $\mathrm{IC}_{10}$ of asexual parasite stages) had the lowest number of gametocytes [104], indicating some preferential killing of gametocytes in these extracts. Some asexual Plasmodium parasite cultures treated with herbal products also had a higher gametocytaemia in comparison to untreated cultures [104], implying that this form of stress (similar to that observed for some antimalarial drugs [105-108]) induces transformation to sexual development. This makes it that much more important to identify compounds that do kill early- and late-stage gametocytes.

\subsection{Endectocidal Activity of Plant Extracts Against Anopheles}

While extracts of plants and plant-derived natural products have been investigated primarily as insecticides or larvacides (reviewed by Rongnoparut et al. [109] and Kishore et al. [110]), their endectocidal activity (where mosquitoes ingest either the extracts of plants or plant-derived compounds and is thereby killed) is poorly explored. A model endectocidal drug for transmission-blocking is ivermectin [111], a 16-membered macrocyclic lactone semisynthetic derivative drug of avermectin, which is a complex natural product originally isolated from the bacterium Streptomyces avermectinius [112,113]. Its MoA is associated with hyperpolarization of cells due to influx of $\mathrm{Cl}^{-}$, due to inhibition of glutamate-gated chloride channels (GluCl) [114,115]. In a clinical study, ivermectin decreased An. gambiae and An. funestus mortality by four to seven-fold, $24 \mathrm{~h}$ after ingestion [116], and kills outdoor-feeding An. arabiensis mosquito vector when delivered through cattle [117] for up to 21 days post-treatment [118]. Enticingly, ivermectin also possesses good activity against asexual $P$. falciparum parasites and late-stage gametocytes ( $\mathrm{IC}_{50^{\prime}} \mathrm{s}$ of 0.1 and $0.5 \mu \mathrm{M}$, respectively, Table S1) [119]. It remains to be seen if this will translate to epidemiological impact in decreasing the parasite transmission burden, in addition to its success against the mosquito vector.

In the search for new endectocides, Kenyan plant species (including Tithonia diversifolia (Asteraceae) and Ricinus communis (Euphorbiaceae)) were active at $\mathrm{LC}_{50}$ values of 8.30 and $8.69 \mathrm{mg} / \mathrm{mL}$ after 3 days and 1.53 and $2.56 \mathrm{mg} / \mathrm{mL}$ after 7 days of feeding, respectively [120], with two active compounds isolated (3-carboxy-4-methoxy- $N$-methyl-2-pyridone and ricinine). Interestingly, the survival of mosquitoes fed on fruits of Mangifera indica (Anacardiaceae) or parts of Thevetia neriifolia (Apocynaceae) or Barleria lupilina (Acanthaceae) was decreased by 50-95\% [121]. A. indica and Z. heitzii extracts also have pronounced endectocitocidal properties [122,123].

\subsection{Transmission-Blocking Activities of Synthetic Derivatives of Natural Compound Analogues Currently in} Clinical Trials

The natural compound analogue and clinical antimalarial drug candidates KAE609 (cipargamin) [124] and OZ439 (artefenomel) (structural design inspired by artemisinin) [125] have transmission-blocking properties both in vitro and in vivo [4,38,126,127]. The spiroindolone KAE609 inhibits in vitro gametocyte development with sub-micromolar concentrations [126], whilst the endoper\{oxide OZ439's potent $\left(\mathrm{IC}_{50}<10 \mathrm{nM}\right)$ gametocytocidal potency is limited to late-stages in vitro [4]. However, OZ439 inhibits exflagellation $(>65 \%$ at $10 \mu \mathrm{M})$ [71] and macro-gametogenesis $\left(\mathrm{IC}_{50}=0.15 \mu \mathrm{M}\right)$ [50]. P. falciparum transmission-blocking of both compounds has been confirmed in vivo [50,126]. Although KAE609 cleared P. vivax gametocytes [127] within $8 \mathrm{~h}$ and OZ439 reduced P. vivax gametocytaemia in vivo by $>90 \%$ within $24 \mathrm{~h}$ [38], the clinical efficacy of both compounds against $P$. falciparum gametocytes still remains inconclusive $[38,127]$. 


\section{Future Perspectives}

While natural product compounds show varied activity against transmission-blocking stages, pragmatic strategies adopted for further discovery of new entities should be refined to ensure selection of high-quality, potent hits to expedite their subsequent discovery and development. This includes stringent selection of natural compound libraries, plants and microbial species to increase the probability of getting hit compounds, given the expansiveness and abundance of the plant kingdom $(>300,000$ plant species on Earth [128]). While the ethnobotany approach has been pivotal in the discovery of chemotherapeutic agents $[29,129]$, unfortunately, transmission-blocking is not a topic one comes across in folk medicine, making it difficult to formulate a question that will lead to identification of plants used for this purpose. Having noted that some plant families e.g. Asteraceae and Meliaceae, are rich sources of prolific compounds potent against most transmission-blocking stages (Figure 1b) [75,82-84,89], a rational approach in selecting plants for screening against sexual stage Plasmodium parasites will have to focus on members of these plant families documented in ethnobotanical surveys. The vast unique marine vegetation that produce novel chemical structures [130] should also be explored for transmission-blocking antimalarials. Novel, previously unculturable bacteria also present huge untapped source of chemical diversity.

Alternative sources are the de novo screen of natural product libraries in medium- to high-throughput format. It is now clearly indicated that driving screens based on asexual stage potency may not identify transmission-blocking specific compounds and as such we recommend parallel screens against different parasite life cycle stages or at the start, screening driven primarily on the transmissible forms, after which activity against other stages can be determined for hits obtained [131,132]. For such natural product libraries, stringent go/no go criteria need to be defined, similar to screening any other small molecule libraries. However, natural product hits need to be clearly evaluated very early on in the screening cascade for drug-like characteristics before proceeding to a hit-to-lead optimisation phase. In line with the innovative thought and approach of the MMV Malaria Boxes [133], we propose the assembling of a box consisting of a set of structurally diverse natural compounds with proven antiplasmodial activity, that could be used as interrogative control set.

Since different assay read-outs might vary with the MoA of small molecules, the reliability of these assay platforms currently used to screen for gametocytocidal activity needs to be rigorously interrogated and 'standardised' to screen extracts against sexual stage Plasmodium parasites at mediumto high-throughput scale. This will need to extend further to clearly defining protocols to adopt such as reference control compounds (and possible extracts) per each stage to be used per assay (providing bench mark $\mathrm{IC}_{50}$ values of each standard reference drug/extract), standard incubation periods and set potency levels (either \% inhibition of development/viability at specified concentration or $\mathrm{IC}_{50}$ values) that will serve to guide as to which extracts will be prioritised for the next phase, that is, isolation, purification and identification of bioactive principles. All of the above is entirely dependent on the ability to isolate and purify bioactive compounds from extracts. Classical bioassay-guided fractionation approaches have been expansively employed within the malaria field [134-136], whilst cutting-edge technologies for improved isolation of bioactive compounds have been developed and should be explored for transmission-blocking discovery [134-138].

There is reason to believe that natural product compounds will retain their potency following oral administration to mosquitoes, such as when it collects a blood meal. On the basis of this knowledge, it is a worth-while effort to screen natural products, reported in literature to be highly potent insecticidal agents, in search of new endectocidal compounds. Another prudent strategy to explore in search of endectocides is to examine natural products known to target unique invertebrate ion channels e.g. $\mathrm{GluCl}$ with the advantage of potential increased selectivity towards mosquitos and therefore reduced toxicity. It remains to be seen if such novel compounds will indeed be able to impact epidemiologically to reduce malaria transmission. 


\section{Concluding Remarks}

Optimal adoption of a transmission-blocking strategy will be crucial for efforts to eliminate and subsequently eradicate malaria to be successful. Perhaps the clearest evidence of the transmission-blocking role of natural products is that currently the only WHO recommended transmission-blocking drug, primaquine, is a derivative of a natural product compound, quinine. It is therefore encouraging to note that natural products do have a potential as a viable rich source of transmission-blocking drugs. The activity of such products described against sexual stage parasites of the two most prevalent malaria causing species, P. falciparum and P. vivax and some of the most prolific Anopheles vector mosquitoes, therefore encourages the further exploration of the vast untapped natural product resources for malaria elimination strategies.

Supplementary Materials: The following are available online at http://www.mdpi.com/1424-8247/13/9/251/s1, Table S1: Supplementary File.

Author Contributions: P.M. conceived the paper and with L.B., prepared the final version. G.M., J.N.E., A.I.L. and V.J.M., reviewed and edited the manuscript. All authors have read and agreed to the published version of the manuscript.

Funding: This work was funded by the South African Research Chairs Initiative of the Department of Science and Technology, administered through the South African National Research Foundation to LMB (UID 84627) and supported by a grant from the NRF (Grant Number 98988) awarded to VJM.

Acknowledgments: The University of Pretoria Institute for Sustainable Malaria Control acknowledges the South Africa Medical Research Council as Collaborating Centre for Malaria Research. We are grateful to D. J. Newman (NIH Special Volunteer) for his comments on the manuscript. Images from Servier Medical Art (SMA) (http://www.servier.com/Powerpoint-image-bank) were used by the authors in creating the graphical abstract and Figure 1. SMA is licensed under the Creative Commons Attribution 3.0 Unported License which promotes unrestricted use (https://creativecommons.org/licenses/by/3.0/)].

Conflicts of Interest: The authors declare no conflict of interest.

\section{References}

1. Cox, F.E. History of the discovery of the malaria parasites and their vectors. Parasites Vectors 2010, 3, 1-9. [CrossRef] [PubMed]

2. Bhatt, S.; Weiss, D.J.; Cameron, E.; Bisanzio, D.; Mappin, B.; Dalrymple, U.; Battle, K.E.; Moyes, C.L.; Henry, A.; Eckhoff, P.A.; et al. The effect of malaria control on Plasmodium falciparum in Africa between 2000 and 2015. Nature 2015, 526, 207-211. [CrossRef] [PubMed]

3. World Health Organization. World Malaria Report 2019; WHO: Geneva, Switzerland, 2019.

4. Plouffe, D.M.; Wree, M.; Du, A.Y.; Meister, S.; Li, F.; Patra, K.; Lubar, A.; Okitsu, S.L.; Flannery, E.L.; Kato, N.; et al. High-Throughput Assay and Discovery of Small Molecules that Interrupt Malaria Transmission. Cell Host Microbe 2016, 19, 114-126. [CrossRef] [PubMed]

5. Lucantoni, L.; Duffy, S.; Adjalley, S.H.; Fidock, D.A.; Avery, V.M. Identification of MMV Malaria Box Inhibitors of Plasmodium falciparum Early-Stage Gametocytes Using a Luciferase-Based High-Throughput Assay. Antimicrob. Agents Chemother. 2013, 57, 6050-6062. [CrossRef] [PubMed]

6. Lucantoni, L.; Fidock, D.A.; Avery, V.M. Luciferase-Based, High-Throughput Assay for Screening and Profiling Transmission-Blocking Compounds against Plasmodium falciparum Gametocytes. Antimicrob. Agents Chemother. 2016, 60, 2097-2107. [CrossRef]

7. Duffy, S.; Avery, V.M. Identification of inhibitors of Plasmodium falciparum gametocyte development. Malar. J. 2013, 12, 408. [CrossRef]

8. Ruecker, A.; Mathias, D.K.; Straschil, U.; Churcher, T.S.; Dinglasan, R.R.; Leroy, D.; Sinden, R.E.; Delves, M. A Male and Female Gametocyte Functional Viability Assay to Identify Biologically Relevant Malaria Transmission-Blocking Drugs. Antimicrob. Agents Chemother. 2014, 58, 7292-7302. [CrossRef]

9. Delves, M.; Ruecker, A.; Straschil, U.; Lelièvre, J.; Marques, S.R.L.O.; López-Barragán, M.J.; Herreros, E.; Sinden, R.E. Male and Female Plasmodium falciparum Mature Gametocytes Show Different Responses to Antimalarial Drugs. Antimicrob. Agents Chemother. 2013, 57, 3268-3274. [CrossRef] 
10. Burrows, J.N.; Duparc, S.; Gutteridge, W.E.; van Huijsduijnen, R.H.; Kaszubska, W.; Macintyre, F.; Mazzuri, S.; Möhrle, J.J.; Wells, T.N. New developments in anti-malarial target candidate and product profiles. Malar. J. 2017, 16, 26. [CrossRef]

11. Butterworth, A.S.; Skinner-Adams, T.S.; Gardiner, D.L.; Trenholme, K.R. Plasmodium falciparum gametocytes: With a view to a kill. Parasitology 2013, 140, 1718-1734. [CrossRef]

12. Kiszewski, A.E. Blocking Plasmodium falciparum Malaria Transmission with Drugs: The Gametocytocidal and Sporontocidal Properties of Current and Prospective Antimalarials. Pharmaceuticals 2010, 4, 44-68. [CrossRef]

13. Roberts, L.; Enserink, M. Did they really say ... eradication? Science 2007, 318, 1544-1545. [CrossRef] [PubMed]

14. Alonso, P.L.; Brown, G.; Arevalo-Herrera, M.; Binka, F.; Chitnis, C.; Collins, F.; Doumbo, O.K.; Greenwood, B.; Hall, B.F.; Levine, M.M. A research agenda to underpin malaria eradication. PLoS Med. 2011, 8, e1000406. [CrossRef] [PubMed]

15. Leroy, D.; Campo, B.; Ding, X.C.; Burrows, J.N.; Cherbuin, S. Defining the biology component of the drug discovery strategy for malaria eradication. Trends Parasitol. 2014, 30, 478-490. [CrossRef] [PubMed]

16. Burrows, J.; Slater, H.; Macintyre, F.; Rees, S.; Thomas, A.; Okumu, F.; van Huijsduijnen, R.H.; Duparc, S.; Wells, T.N. A discovery and development roadmap for new endectocidal transmission-blocking agents in malaria. Malar. J. 2018, 17, 462. [CrossRef] [PubMed]

17. Shretta, R.; Liu, J.; Cotter, C.; Cohen, J.; Dolenz, C.; Makomva, K.; Newby, G.; Ménard, D.; Phillips, A.; Tatarsky, A.; et al. Malaria Elimination and Eradication. In Major Infectious Diseases, 3rd ed.; The International Bank for Reconstruction and Development/The World Bank: Washington, DC, USA, 2017; pp. 315-346.

18. Killeen, G.F.; Tatarsky, A.; Diabate, A.; Chaccour, C.J.; Marshall, J.M.; Okumu, F.O.; Brunner, S.; Newby, G.; Williams, Y.A.; Malone, D.; et al. Developing an expanded vector control toolbox for malaria elimination. BMJ Glob. Health 2017, 2, e000211. [CrossRef] [PubMed]

19. Rueda-Zubiaurre, A.; Yahiya, S.; Fischer, O.J.; Hu, X.; Saunders, C.N.; Sharma, S.; Straschil, U.; Shen, J.; Tate, E.W.; Delves, M.J.; et al. Structure-Activity Relationship Studies of a Novel Class of Transmission Blocking Antimalarials Targeting Male Gametes. J. Med. Chem. 2019, 63, 2240-2262. [CrossRef] [PubMed]

20. Song, J.; Duong, S.; Tan, B.; Dara, P.; Deng, C.; Sreng, S.; Seila, S.; Ou, F.; Jian, H.; Li, G. Rapid and effective malaria control in Cambodia through mass administration of artemisinin-piperaquine. Malar. J. 2010, 9, 57. [CrossRef]

21. Shekalaghe, S.; Drakeley, C.; Gosling, R.; Ndaro, A.; Van Meegeren, M.; Enevold, A.; Alifrangis, M.; Mosha, F.; Sauerwein, R.; Bousema, T. Primaquine Clears Submicroscopic Plasmodium falciparum Gametocytes that Persist after Treatment with Sulphadoxine-Pyrimethamine and Artesunate. PLoS ONE 2007, 2, e1023. [CrossRef]

22. Smithuis, F.; Kyaw, M.K.; Phe, O.; Win, T.; Aung, P.P.; Oo, A.P.P.; Naing, A.L.; Nyo, M.Y.; Myint, N.Z.H.; Imwong, M.; et al. Effectiveness of five artemisinin combination regimens with or without primaquine in uncomplicated falciparum malaria: An open-label randomised trial. Lancet Infect. Dis. 2010, 10, 673-681. [CrossRef]

23. Okebe, J.; Bousema, T.; Affara, M.; Di Tanna, G.L.; Dabira, E.; Gaye, A.; Sanya-Isijola, F.; Badji, H.; Correa, S.; Nwakanma, D.; et al. The Gametocytocidal Efficacy of Different Single Doses of Primaquine with Dihydroartemisinin-piperaquine in Asymptomatic Parasite Carriers in The Gambia: A Randomized Controlled Trial. EBioMedicine 2016, 13, 348-355. [CrossRef] [PubMed]

24. Raman, J.; Allen, E.; Workman, L.; Mabuza, A.; Swanepoel, H.; Malatje, G.; Frean, J.; Wiesner, L.; Barnes, K.I. Safety and tolerability of single low-dose primaquine in a low-intensity transmission area in South Africa: An open-label, randomized controlled trial. Malar. J. 2019, 18, 1-13. [CrossRef] [PubMed]

25. World Health Organization. Guidelines for the Treatment of Malaria; WHO: Geneva, Switzerland, 2015.

26. Newman, D.J.; Cragg, G.M. Natural Products as Sources of New Drugs from 1981 to 2014. J. Nat. Prod. 2016, 79, 629-661. [CrossRef] [PubMed]

27. Newman, D.J.; Cragg, G.M. Natural products as sources of new drugs over the nearly four decades from 01/1981 to 09/2019. J. Nat. Prod. 2020, 83, 770-803. [CrossRef] [PubMed]

28. Wells, T.N. Natural products as starting points for future anti-malarial therapies: Going back to our roots? Malar. J. 2011, 10, S3. [CrossRef] 
29. Tu, Y. The discovery of artemisinin (qinghaosu) and gifts from Chinese medicine. Nat. Med. 2011, 17, 1217-1220. [CrossRef]

30. Gaillard, T.; Dormoi, J.; Madamet, M.; Pradines, B. Macrolides and associated antibiotics based on similar mechanism of action like lincosamides in malaria. Malar. J. 2016, 15, 85. [CrossRef]

31. Gaillard, T.; Madamet, M.; Pradines, B. Tetracyclines in malaria. Malar. J. 2015, 14, 445. [CrossRef]

32. Harvey, A.L.; Edrada-Ebel, R.; Quinn, R.J. The re-emergence of natural products for drug discovery in the genomics era. Nat. Rev. Drug Discov. 2015, 14, 111-129. [CrossRef]

33. Li, F.; Wang, Y.; Li, D.; Chen, Y.; Dou, Q.P. Are we seeing a resurgence in the use of natural products for new drug discovery? Expert Opin. Drug Discov. 2019, 14, 417-420. [CrossRef]

34. Ling, L.L.; Schneider, T.; Peoples, A.J.; Spoering, A.L.; Engels, I.; Conlon, B.P.; Mueller, A.; Schäberle, T.F.; Hughes, D.E.; Epstein, S.; et al. A new antibiotic kills pathogens without detectable resistance. Nature 2015, 517, 455. [CrossRef] [PubMed]

35. Imai, Y.; Meyer, K.J.; Iinishi, A.; Favre-Godal, Q.; Green, R.; Manuse, S.; Caboni, M.; Mori, M.; Niles, S.; Ghiglieri, M.; et al. A new antibiotic selectively kills Gram-negative pathogens. Nature 2019, 576, 459-464. [CrossRef] [PubMed]

36. D'Incalci, M.; Galmarini, C.M. A Review of Trabectedin (ET-743): A Unique Mechanism of Action. Mol. Cancer Ther. 2010, 9, 2157-2163. [CrossRef] [PubMed]

37. Stein, D.S.; Jain, J.P.; Kangas, M.; Lefèvre, G.; Machineni, S.; Griffin, P.; Lickliter, J. Open-Label, Single-Dose, Parallel-Group Study in Healthy Volunteers To Determine the Drug-Drug Interaction Potential between KAE609 (Cipargamin) and Piperaquine. Antimicrob. Agents Chemother. 2015, 59, 3493-3500. [CrossRef]

38. Phyo, A.P.; Jittamala, P.; Nosten, F.; Pukrittayakamee, S.; Imwong, M.; White, N.J.; Duparc, S.; MacIntyre, F.; Baker, M.; Möhrle, J.J. Antimalarial activity of artefenomel (OZ439), a novel synthetic antimalarial endoperoxide, in patients with Plasmodium falciparum and Plasmodium vivax malaria: An open-label phase 2 trial. Lancet Infect. Dis. 2016, 16, 61-69. [CrossRef]

39. Yoo, E.; Schulze, C.J.; Stokes, B.H.; Onguka, O.; Yeo, T.; Mok, S.; Gnädig, N.F.; Zhou, Y.; Kurita, K.; Foe, I.T.; et al. The Antimalarial Natural Product Salinipostin a Identifies Essential $\alpha / \beta$ Serine Hydrolases Involved in Lipid Metabolism in P. Falciparum Parasites. Cell Chem. Biol. 2020, 27, 143-157. [CrossRef]

40. Birkholtz, L.M.; Coetzer, T.L.; Mancama, D.; Leroy, D.; Alano, P. Discovering New Transmission-Blocking Antimalarial Compounds: Challenges and Opportunities. Trends parasitol. 2016, 32, 669-681. [CrossRef]

41. Delves, M.; Miguel-Blanco, C.; Matthews, H.; Molina, I.; Ruecker, A.; Yahiya, S.; Straschil, U.; Abraham, M.; León, M.L.; Fischer, O.; et al. A high throughput screen for next-generation leads targeting malaria parasite transmission. Nat. Commun. 2018, 9, 3805. [CrossRef]

42. Miguel-Blanco, C.; Molina, I.; Bardera, A.I.; Díaz, B.; de Las Heras, L.; Lozano, S.; González, C.; Rodrigues, J.; Delves, M.J.; Ruecker, A.; et al. Hundreds of dual-stage antimalarial molecules discovered by a functional gametocyte screen. Nat. Commun. 2017, 8, 15160. [CrossRef]

43. Delves, M.; Lafuente-Monasterio, M.J.; Upton, L.; Ruecker, A.; Leroy, D.; Gamo, F.-J.; Sinden, R. Fueling Open Innovation for Malaria Transmission-Blocking Drugs: Hundreds of Molecules Targeting Early Parasite Mosquito Stages. Front. Microbiol. 2019, 10, 2134. [CrossRef]

44. Azzaz, H.H.; Murad, H.A.; Morsy, T.A. Utility of ionophores for ruminant animals: A review. Asian J. Anim. Sci. 2015, 9, 254-265.

45. D'Alessandro, S.; Corbett, Y.; Ilboudo, D.P.; Misiano, P.; Dahiya, N.; Abay, S.M.; Habluetzel, A.; Grande, R.; Gismondo, M.R.; Dechering, K.J.; et al. Salinomycin and Other Ionophores as a New Class of Antimalarial Drugs with Transmission-Blocking Activity. Antimicrob. Agents Chemother. 2015, 59, 5135-5144. [CrossRef] [PubMed]

46. Rutkowski, J.; Brzezinski, B. Structures and Properties of Naturally Occurring Polyether Antibiotics. BioMed Res. Int. 2013, 2013, 1-31. [CrossRef] [PubMed]

47. Fleck, W.F.; Strauss, D.G.; Meyer, J.; Porstendorfer, G. Fermentation, isolation, and biological activity of maduramycin: A new antibiotic from Actinomadura rubra. Z. Allg. Mikrobiol. 1978, 18, 389-398. [CrossRef] [PubMed]

48. Maron, M.I.; Magle, C.T.; Czesny, B.; Turturice, B.A.; Huang, R.; Zheng, W.; Vaidya, A.B.; Williamson, K.C. Maduramicin Rapidly Eliminates Malaria Parasites and Potentiates the Gametocytocidal Activity of the Pyrazoleamide PA21A050. Antimicrob. Agents Chemother. 2016, 60, 1492-1499. [CrossRef] [PubMed] 
49. Sun, W.; Tanaka, T.Q.; Magle, C.T.; Huang, W.; Southall, N.; Huang, R.; Dehdashti, S.J.; McKew, J.C.; Williamson, K.C.; Zheng, W. Chemical signatures and new drug targets for gametocytocidal drug development. Sci. Rep. 2014, 4, 3743. [CrossRef] [PubMed]

50. Bolscher, J.M.; Koolen, K.M.J.; Van Gemert, G.J.; Van De Vegte-Bolmer, M.G.; Bousema, T.; Leroy, D.; Sauerwein, R.W.; Dechering, K.J. A combination of new screening assays for prioritization of transmission-blocking antimalarials reveals distinct dynamics of marketed and experimental drugs. J. Antimicrob. Chemother. 2015, 70, 1357-1366. [CrossRef] [PubMed]

51. Lelièvre, J.; Almela, M.J.; Lozano, S.; Miguel, C.; Franco, V.; Leroy, D.; Herreros, E. Activity of clinically relevant antimalarial drugs on Plasmodium falciparum mature gametocytes in an ATP bioluminescence "transmission blocking" assay. PLoS ONE 2012, 7, e35019. [CrossRef] [PubMed]

52. Almela, M.J.; Lozano, S.; Lelievre, J.; Colmenarejo, G.; Coterón, J.M.; Rodrigues, J.; González, C.; Herreros, E. A New Set of Chemical Starting Points with Plasmodium falciparum Transmission-Blocking Potential for Antimalarial Drug Discovery. PLoS ONE 2015, 10, e0135139. [CrossRef] [PubMed]

53. D'Alessandro, S.; Silvestrini, F.; Dechering, K.; Corbett, Y.; Parapini, S.; Timmerman, M.; Galastri, L.; Basilico, N.; Sauerwein, R.; Alano, P.; et al. A Plasmodium falciparum screening assay for anti-gametocyte drugs based on parasite lactate dehydrogenase detection. J. Antimicrob. Chemother. 2013, 68, 2048-2058. [CrossRef] [PubMed]

54. D’Alessandro, S.; Camarda, G.; Corbett, Y.; Siciliano, G.; Parapini, S.; Cevenini, L.; Michelini, E.; Roda, A.; Leroy, D.; Taramelli, D. A chemical susceptibility profile of the Plasmodium falciparum transmission stages by complementary cell-based gametocyte assays. J. Antimicrob. Chemother. 2016, 71, 1148-1158. [CrossRef] [PubMed]

55. Czesny, B.; Goshu, S.; Cook, J.L.; Williamson, K.C. The Proteasome Inhibitor Epoxomicin Has Potent Plasmodium falciparum Gametocytocidal Activity. Antimicrob. Agents Chemother. 2009, 53, 4080-4085. [CrossRef] [PubMed]

56. Aminake, M.N.; Arndt, H.D.; Pradel, G. The proteasome of malaria parasites: A multi-stage drug target for chemotherapeutic intervention? Int. J. Parasitol. Drugs Drug Resist. 2012, 2, 1-10. [CrossRef] [PubMed]

57. LaMonte, G.M.; Almaliti, J.; Bibo-Verdugo, B.; Keller, L.; Zou, B.Y.; Yang, J.; Antonova-Koch, Y.; Orjuela-Sanchez, P.; Boyle, C.A.; Vigil, E.; et al. Development of a Potent Inhibitor of the Plasmodium Proteasome with Reduced Mammalian Toxicity. J. Med. Chem. 2017, 60, 6721-6732. [CrossRef] [PubMed]

58. Aminake, M.N.; Schoof, S.; Sologub, L.; Leubner, M.; Kirschner, M.; Arndt, H.D.; Pradel, G. Thiostrepton and derivatives exhibit antimalarial and gametocytocidal activity by dually targeting parasite proteasome and apicoplast. Antimicrob. Agents Chemother. 2011, 55, 1338-1348. [CrossRef]

59. Azevedo, R.; Markovic, M.; Machado, M.; Franke-Fayard, B.; Mendes, A.M.; Prudêncio, M. Bioluminescence Method for In Vitro Screening of Plasmodium Transmission-Blocking Compounds. Antimicrob. Agents Chemother. 2017, 61, 02699-16. [CrossRef]

60. Saraiva, R.G.; Huitt-Roehl, C.R.; Tripathi, A.K.; Cheng, Y.-Q.; Bosch, J.; Townsend, C.A.; Dimopoulos, G. Chromobacterium spp. mediate their anti-Plasmodium activity through secretion of the histone deacetylase inhibitor romidepsin. Sci. Rep. 2018, 8, 6176. [CrossRef]

61. Delves, M.J.; Ramakrishnan, C.; Blagborough, A.M.; Leroy, D.; Wells, T.N.; Sinden, R.E. A high-throughput assay for the identification of malarial transmission-blocking drugs and vaccines. Int. J. Parasitol. 2012, 42, 999-1006. [CrossRef]

62. Held, J.; Gebru, T.; Kalesse, M.; Jansen, R.; Gerth, K.; Müller, R.; Mordmüller, B. Antimalarial activity of the myxobacterial macrolide chlorotonil A. Antimicrob. Agents Chemother. 2014, 58, 6378-6384. [CrossRef]

63. Vos, M.W.; Stone, W.J.R.; Koolen, K.M.; Van Gemert, G.-J.; Van Schaijk, B.; Leroy, D.; Sauerwein, R.W.; Bousema, T.; Dechering, K.J. A semi-automated luminescence based standard membrane feeding assay identifies novel small molecules that inhibit transmission of malaria parasites by mosquitoes. Sci. Rep. 2015, 5, 18704. [CrossRef]

64. Pastrana-Mena, R.; Mathias, D.K.; Delves, M.; Rajaram, K.; King, J.G.; Yee, R.; Trucchi, B.; Verotta, L.; Dinglasan, R.R. A Malaria Transmission-Blocking (+)-Usnic Acid Derivative PreventsPlasmodiumZygote-to-Ookinete Maturation in the Mosquito Midgut. ACS Chem. Biol. 2016, 11, 3461-3472. [CrossRef] [PubMed]

65. Zhang, G.; Niu, G.; Franca, C.M.; Dong, Y.; Wang, X.; Butler, N.S.; Dimopoulos, G.; Li, J. Anopheles Midgut FREP1 Mediates Plasmodium Invasion. J. Boil. Chem. 2015, 290, 16490-16501. [CrossRef] [PubMed] 
66. Niu, G.; Wang, B.; Zhang, G.; King, J.B.; Cichewicz, R.H.; Li, J. Targeting mosquito FREP1 with a fungal metabolite blocks malaria transmission. Sci. Rep. 2015, 5, 14694. [CrossRef] [PubMed]

67. Bucknall, R.A.; Moores, H.; Simms, R.; Hesp, B. Antiviral Effects of Aphidicolin, a New Antibiotic Produced by Cephalosporium aphidicola. Antimicrob. Agents Chemother. 1973, 4, 294-298. [CrossRef] [PubMed]

68. Janse, C.J.; Van Der Klooster, P.F.; Van Der Kaay, H.J.; Van Der Ploeg, M.; Overdulve, J.P. DNA synthesis in Plasmodium berghei during asexual and sexual development. Mol. Biochem. Parasitol. 1986, 20, 173-182. [CrossRef]

69. Daina, A.; Michielin, O.; Zoete, V. SwissADME: A free web tool to evaluate pharmacokinetics, drug-likeness and medicinal chemistry friendliness of small molecules. Sci. Rep. 2017, 7, 42717. [CrossRef]

70. Peatey, C.L.; Leroy, D.; Gardiner, D.L.; Trenholme, K.R. Anti-malarial drugs: How effective are they against Plasmodium falciparum gametocytes? Malar. J. 2012, 11, 34. [CrossRef]

71. Delves, M.; Plouffe, D.; Scheurer, C.; Meister, S.; Wittlin, S.; Winzeler, E.A.; Sinden, R.E.; Leroy, D. The Activities of Current Antimalarial Drugs on the Life Cycle Stages of Plasmodium: A Comparative Study with Human and Rodent Parasites. PLoS Med. 2012, 9, e1001169. [CrossRef]

72. Bousema, J.T.; Schneider, P.; Gouagna, L.C.; Drakeley, C.; Tostmann, A.; Houben, R.; Githure, J.I.; Ord, R.; Sutherland, C.J.; Omar, S.A.; et al. Moderate Effect of Artemisinin-Based Combination Therapy on Transmission of Plasmodium falciparum. J. Infect. Dis. 2006, 193, 1151-1159. [CrossRef]

73. Price, R.N.; Nosten, F.; Luxemburger, C.; Ter Kuile, F.O.; Paiphun, L.; Chongsuphajaisiddhi, T.; White, N. Effects of artemisinin derivatives on malaria transmissibility. Lancet 1996, 347, 1654-1658. [CrossRef]

74. White, N.J.; Ashley, E.A.; Recht, J.; Delves, M.; Ruecker, A.; Smithuis, F.; Eziefula, A.C.; Bousema, T.; Drakeley, C.; Chotivanich, K.; et al. Assessment of therapeutic responses to gametocytocidal drugs in Plasmodium falciparum malaria. Malar. J. 2014, 13, 483. [CrossRef] [PubMed]

75. Balaich, J.N.; Mathias, D.K.; Torto, B.; Jackson, B.T.; Tao, D.; Ebrahimi, B.; Tarimo, B.B.; Cheseto, X.; Foster, W.A.; Dinglasan, R.R. The Nonartemisinin Sesquiterpene Lactones Parthenin and Parthenolide Block Plasmodium falciparum Sexual Stage Transmission. Antimicrob. Agents Chemother. 2016, 60, 2108-2117. [CrossRef] [PubMed]

76. Moyo, P.; Kunyane, P.; Selepe, M.A.; Eloff, J.N.; Niemand, J.; Louw, A.I.; Maharaj, V.J.; Birkholtz, L.-M. Bioassay-guided isolation and identification of gametocytocidal compounds from Artemisia afra (Asteraceae). Malar. J. 2019, 18, 65. [CrossRef] [PubMed]

77. Abay, S.M.; Lucantoni, L.; Dahiya, N.; Dori, G.U.; Dembo, E.G.; Esposito, F.; Lupidi, G.; Ogboi, J.S.; Ouédraogo, R.K.; Sinisi, A.; et al. Plasmodium transmission blocking activities of Vernonia amygdalina extracts and isolated compounds. Malar. J. 2015, 14, 288. [CrossRef]

78. Sirignano, C.; Snene, A.; Rigano, D.; Tapanelli, S.; Formisano, C.; Luciano, P.; El Mokni, R.; Hammami, S.; Tenoh, A.R.; Habluetzel, A.; et al. Angeloylated Germacranolides from Daucus virgatus and Their Plasmodium Transmission Blocking Activity. J. Nat. Prod. 2017. [CrossRef]

79. Sirignano, C.; Snene, A.; Tenoh, A.R.; El Mokni, R.; Rigano, D.; Habluetzel, A.; Hammami, S.; Taglialatela-Scafati, O. Daucovirgolides I-L, four congeners of the antimalarial daucovirgolide G from Daucus virgatus. Fitoterapia 2019, 137, 104188. [CrossRef]

80. Wani, M.C.; Taylor, H.L.; Wall, M.E.; Coggon, P.; McPhail, A.T. Plant antitumor agents. VI. Isolation and structure of taxol, a novel antileukemic and antitumor agent from Taxus brevifolia. J. Am. Chem. Soc. 1971, 93, 2325-2327. [CrossRef]

81. Kumar, N.; Aikawa, M.; Grotendorst, C. Plasmodium gallinaceum: Critical role for microtubules in the transformation of zygotes into ookinetes. Exp. Parasitol. 1985, 59, 239-247. [CrossRef]

82. Jones, I.W.; Denholm, A.A.; Ley, S.V.; Lovell, H.; Wood, A.; Sinden, R.E. Sexual development of malaria parasites is inhibited in vitro by the neem extract azadirachtin, and its semi-synthetic analogues. FEMS Microbiol. Lett. 1994, 120, 267-273. [CrossRef]

83. Lucantoni, L.; Yerbanga, S.R.; Lupidi, G.; Pasqualini, L.; Esposito, F.; Habluetzel, A. Transmission blocking activity of a standardized neem (Azadirachta indica) seed extract on the rodent malaria parasite Plasmodium berghei in its vector Anopheles stephensi. Malar. J. 2010, 9, 66. [CrossRef]

84. Yerbanga, S.R.; Lucantoni, L.; Ouédraogo, R.K.; Da, D.F.; Yao, F.A.; Yameogo, B.; Churcher, T.S.; Lupidi, G.; Taglialatela-Scafati, O.; Gouagna, L.C.; et al. Transmission blocking activity of Azadirachta indica and Guiera senegalensis extracts on the sporogonic development of Plasmodium falciparum field isolates in Anopheles coluzzii mosquitoes. Parasites Vectors 2014, 7, 185. [CrossRef] [PubMed] 
85. Dhar, R.; Zhang, K.; Talwar, G.P.; Garg, S.; Kumar, N. Inhibition of the growth and development of asexual and sexual stages of drug-sensitive and resistant strains of the human malaria parasite Plasmodium falciparum by Neem (Azadirachta indica) fractions. J. Ethnopharmacol. 1998, 61, 31-39. [CrossRef]

86. Udeinya, J.I.; Shu, E.; Quakyi, I.; Ajayi, F. An Antimalarial Neem Leaf Extract has Both Schizonticidal and Gametocytocidal Activities. Am. J. Ther. 2008, 15, 108-110. [CrossRef] [PubMed]

87. Udeinya, I.J.; Brown, N.; Shu, E.N.; Udeinya, F.I.; Quakeyie, I. Fractions of an antimalarial neem-leaf extract have activities superior to chloroquine, and are gametocytocidal. Ann. Trop. Med. Parasitol. 2006, 100, 17-22. [CrossRef]

88. Dahiya, N.; Chianese, G.; Abay, S.M.; Taglialatela-Scafati, O.; Esposito, F.; Lupidi, G.; Bramucci, M.; Quassinti, L.; Christophides, G.K.; Habluetzel, A.; et al. In vitro and ex vivo activity of an Azadirachta indica A.Juss. seed kernel extract on early sporogonic development of Plasmodium in comparison with azadirachtin A, its most abundant constituent. Phytomedicine 2016, 23, 1743-1752. [CrossRef]

89. Tapanelli, S.; Chianese, G.; Lucantoni, L.; Yerbanga, R.S.; Habluetzel, A.; Taglialatela-Scafati, O. Transmission blocking effects of neem (Azadirachta indica) seed kernel limonoids on Plasmodium berghei early sporogonic development. Fitoterapia 2016, 114, 122-126. [CrossRef]

90. Billker, O.; Shaw, M.K.; Jones, I.W.; Ley, S.V.; Mordue, A.J.; Sinden, R.E. Azadirachtin Disrupts Formation of Organised Microtubule Arrays during Microgametogenesis of Plasmodium berghei. J. Eukaryot. Microbiol. 2002, 49, 489-497. [CrossRef]

91. Bousema, T.; Okell, L.; Shekalaghe, S.; Griffin, J.; Omar, S.; Sawa, P.; Sutherland, C.; Sauerwein, R.; Ghani, A.C.; Drakeley, C. Revisiting the circulation time of Plasmodium falciparum gametocytes: Molecular detection methods to estimate the duration of gametocyte carriage and the effect of gametocytocidal drugs. Malar. J. 2010, 9, 136. [CrossRef]

92. Mackerras, M.; Ercole, Q. Observations on the action of quinine, atebrin and plasmoquine on the gametocytes of Plasmodium falciparum. Trans. R. Soc. Trop. Med. Hyg. 1949, 42, 455-463. [CrossRef]

93. Achan, J.; Talisuna, A.O.; Erhart, A.; Yeka, A.; Tibenderana, J.K.; Baliraine, F.N.; Rosenthal, P.J.; D'Alessandro, U. Quinine, an old anti-malarial drug in a modern world: Role in the treatment of malaria. Malar. J. 2011, 10, 144. [CrossRef]

94. Goodman, C.D.; Austarheim, I.; Mollard, V.; Mikolo, B.; Malterud, K.E.; McFadden, G.I.; Wangensteen, H. Natural products from Zanthoxylum heitzii with potent activity against the malaria parasite. Malar. J. 2016, 15, 1-8. [CrossRef] [PubMed]

95. Onambele, L.A.; Riepl, H.; Fischer, R.; Pradel, G.; Prokop, A.; Aminake, M.N. Synthesis and evaluation of the antiplasmodial activity of tryptanthrin derivatives. Int. J. Parasitol. Drugs Drug Resist. 2015, 5, 48-57. [CrossRef] [PubMed]

96. Forkuo, A.D.; Ansah, C.; Gyan, B.; Mancama, D.; Theron, A. In vitro antimalarial interaction and transmission-blocking activity of cryptolepine. Planta Medica 2016, 81, S1-S381.

97. Wright, C.W.; Addae-Kyereme, J.; Breen, A.G.; Brown, J.E.; Cox, M.F.; Croft, S.L.; Gökçek, Y.; Kendrick, H.; Phillips, R.M.; Pollet, P.L. Synthesis and evaluation of cryptolepine analogues for their potential as new antimalarial agents. J. Med. Chem. 2001, 44, 3187-3194. [CrossRef]

98. Arango, E.M.; Londoño, B.; Segura, C.; Solarte, Y.; Herrera, S.; Saez, J.; Blair, S.; Carmona-Fonseca, J.; Londono-Renteria, B.L. Prevention of sporogony ofPlasmodium vivax inAnopheles albimanus by steroids ofSolanum nudum Dunal (Solanaceae). Phytotherapy Res. 2006, 20, 444-447. [CrossRef]

99. Krieg, R.; Jortzik, E.; Goetz, A.A.; Blandin, S.; Wittlin, S.; Elhabiri, M.; Rahbari, M.; Nuryyeva, S.; Voigt, K.; Dahse, H.M. Arylmethylamino steroids as antiparasitic agents. Nat. Comm. 2017, 8, 1-12. [CrossRef]

100. Soré, H.; D’Alessandro, S.; Sanon, S.; Parapini, S.; Tiono, A.; Valea, I.; Sirima, S.; Hilou, A.; Taramelli, D. In vitro inhibitory activity against plasmodium falciparum sexual and asexual stages of medicinal plants used in burkina. Int. J. Curr. Med. Pharm. Res. 2017, 4, 2976-2983.

101. Lopatriello, A.; Soré, H.; Habluetzel, A.; Parapini, S.; D’Alessandro, S.; Taramelli, D.; Taglialatela-Scafati, O. Identification of a potent and selective gametocytocidal antimalarial agent from the stem barks of Lophira lanceolata. Bioorganic Chem. 2019, 93, 103321. [CrossRef]

102. Soré, H.; Lopatriello, A.; Ebstie, Y.A.; Guedoung, A.R.T.; Hilou, A.; Pereira, J.A.; Kijjoa, A.; Habluetzel, A.; Taglialatela-Scafati, O. Plasmodium stage-selective antimalarials from Lophira lanceolata stem bark. Phytochemistry 2020, 174, 112336. [CrossRef] 
103. Paton, D.G.; Childs, L.M.; Itoe, M.A.; Holmdahl, I.E.; Buckee, C.O.; Catteruccia, F. Exposing Anopheles mosquitoes to antimalarials blocks Plasmodium parasite transmission. Nature 2019, 567, 239. [CrossRef]

104. Amoah, L.E.; Kakaney, C.; Kwansa-Bentum, B.; Asamoah Kusi, K. Activity of Herbal Medicines on Plasmodium falciparum Gametocytes: Implications for Malaria Transmission in Ghana. PLoS ONE 2015, 10, e0142587. [CrossRef] [PubMed]

105. Buckling, A.; Crooks, L.; Read, A. Plasmodium chabaudi: Effect of antimalarial drugs on gametocytogenesis. Exp. Parasitol. 1999, 93, 45-54. [CrossRef] [PubMed]

106. Osorio, L.; Gonzalez, I.; Olliaro, P.; Taylor, W.R. Artemisinin-based combination therapy for uncomplicated Plasmodium falciparum malaria in Colombia. Malar. J. 2007, 6. [CrossRef] [PubMed]

107. Peatey, C.L.; Skinner-Adams, T.S.; Dixon, M.W.; McCarthy, J.S.; Gardiner, D.L.; Trenholme, K.R. Effect of antimalarial drugs on Plasmodium falciparum gametocytes. J. Infect. Dis. 2009, 200, 1518-1521. [CrossRef] [PubMed]

108. Sowunmi, A.; Fateye, B. Plasmodium falciparum gametocytaemia in Nigerian children: Before, during and after treatment with antimalarial drugs. Trop. Med. Int. Health 2003, 8, 783-792. [CrossRef] [PubMed]

109. Rongnoparut, P.; Duangkaew, P.; Prasopthum, A.; Pouyfung, P. Structure-Function Relationships of Phytochemicals in Control of Mosquito Vectors. Curr. Org. Chem. 2016, 20, 2649-2673. [CrossRef]

110. Kishore, N.; Mishra, B.B.; Tiwari, V.K.; Tripathi, V.; Lall, N. Natural products as leads to potential mosquitocides. Phytochem. Rev. 2014, 13, 587-627. [CrossRef]

111. Chaccour, C.; Rabinovich, N.R. Ivermectin to reduce malaria transmission II. Considerations regarding clinical development pathway. Malar. J. 2017, 16, 166. [CrossRef]

112. Õmura, S.; Crump, A. The life and times of ivermectin-A success story. Nat. Rev. Microbiol. 2004, 2, 984-989. [CrossRef]

113. Chaccour, C.J.; Kobylinski, K.C.; Bassat, Q.; Bousema, T.; Drakeley, C.; Alonso, P.; Foy, B.D. Ivermectin to reduce malaria transmission: A research agenda for a promising new tool for elimination. Malar. J. 2013, 12, 153. [CrossRef]

114. Campbell, W.; Fisher, M.; Stapley, E.; Albers-Schonberg, G.; Jacob, T. Ivermectin: A potent new antiparasitic agent. Science 1983, 221, 823-828. [CrossRef] [PubMed]

115. Yates, D.M.; Wolstenholme, A.J. An ivermectin-sensitive glutamate-gated chloride channel subunit from Dirofilaria immitis. Int. J. Parasitol. 2004, 34, 1075-1081. [CrossRef] [PubMed]

116. Ouédraogo, A.L.; Bastiaens, G.J.; Tiono, A.B.; Guelbéogo, W.M.; Kobylinski, K.C.; Ouédraogo, A.; Barry, A.; Bougouma, E.C.; Nebie, I.; San Ouattara, M. Efficacy and safety of the mosquitocidal drug ivermectin to prevent malaria transmission after treatment: A double-blind, randomized, clinical trial. Clin. Infect. Dis. 2015, 60, 357-365. [CrossRef] [PubMed]

117. Shoop, W.; Egerton, J.; Eary, C.; Haines, H.; Michael, B.; Mrozik, H.; Eskola, P.; Fisher, M.; Slayton, L.; Ostlind, D. Eprinomectin: A novel avermectin for use as a topical endectocide for cattle. Int. J. Parasitol. 1996, 26, 1237-1242. [CrossRef]

118. Poché, R.M.; Burruss, D.; Polyakova, L.; Poché, D.M.; Garlapati, R.B. Treatment of livestock with systemic insecticides for control of Anopheles arabiensis in western Kenya. Malar. J. 2015, 14, 351. [CrossRef]

119. De Carvalho, L.P.; Sandri, T.L.; de Melo, E.J.T.; Fendel, R.; Kremsner, P.G.; Mordmüller, B.; Held, J. Ivermectin impairs the development of sexual and asexual stages of Plasmodium falciparum in vitro. Antimicrob. Agents Chemother. 2019, 63, e00085-19. [CrossRef]

120. Wachira, S.W.; Omar, S.; Jacob, J.W.; Wahome, M.; Alborn, H.T.; Spring, D.R.; Masiga, D.K.; Torto, B. Toxicity of six plant extracts and two pyridone alkaloids from Ricinus communis against the malaria vector Anopheles gambiae. Parasites Vectors 2014, 7, 312. [CrossRef]

121. Hien, D.F.D.S.; Dabiré, K.R.; Roche, B.; Diabaté, A.; Yerbanga, R.S.; Cohuet, A.; Yameogo, B.K.; Gouagna, L.-C.; Hopkins, R.J.; Ouedraogo, G.A. Plant-mediated effects on mosquito capacity to transmit human malaria. PLoS Pathog. 2016, 12, e1005773. [CrossRef]

122. Dembo, E.G.; Abay, S.M.; Dahiya, N.; Ogboi, J.S.; Christophides, G.K.; Lupidi, G.; Chianese, G.; Lucantoni, L.; Habluetzel, A. Impact of repeated NeemAzal ${ }^{\circledR}$-treated blood meals on the fitness of Anopheles stephensi mosquitoes. Parasites Vectors 2015, 8, 1-13. [CrossRef]

123. Overgaard, H.J.; Sirisopa, P.; Mikolo, B.; Malterud, K.E.; Wangensteen, H.; Zou, Y.-F.; Paulsen, B.S.; Massamba, D.; Duchon, S.; Corbel, V. Insecticidal activities of bark, leaf and seed extracts of Zanthoxylum heitzii against the African malaria vector Anopheles gambiae. Molecules 2014, 19, 21276-21290. [CrossRef] 
124. Rottmann, M.; McNamara, C.; Yeung, B.K.; Lee, M.C.; Zou, B.; Russell, B.; Seitz, P.; Plouffe, D.M.; Dharia, N.V.; Tan, J. Spiroindolones, a new and potent chemotype for the treatment of malaria. Science 2010, 329, 1175. [CrossRef] [PubMed]

125. Charman, S.A.; Arbe-Barnes, S.; Bathurst, I.C.; Brun, R.; Campbell, M.; Charman, W.N.; Chiu, F.C.; Chollet, J.; Craft, J.C.; Creek, D.J. Synthetic ozonide drug candidate OZ439 offers new hope for a single-dose cure of uncomplicated malaria. Proc. Natl. Acad. Sci. USA 2011, 108, 4400-4405. [CrossRef] [PubMed]

126. Van Pelt-Koops, J.C.; Pett, H.E.; Graumans, W.; Van Der Vegte-Bolmer, M.; Van Gemert, G.J.; Rottmann, M.; Yeung, B.K.; Diagana, T.T.; Sauerwein, R.W. The Spiroindolone Drug Candidate NITD609 Potently Inhibits Gametocytogenesis and Blocks Plasmodium falciparum Transmission to Anopheles Mosquito Vector. Antimicrob. Agents Chemother. 2012, 56, 3544-3548. [CrossRef] [PubMed]

127. White, N.J.; Pukrittayakamee, S.; Phyo, A.P.; Rueangweerayut, R.; Nosten, F.; Jittamala, P.; Jeeyapant, A.; Jain, J.P.; Lefèvre, G.; Li, R. Spiroindolone KAE609 for falciparum and vivax malaria. N. Engl. J. Med. 2014, 371, 403-410. [CrossRef]

128. Lughadha, E.N.; Govaerts, R.; Belyaeva, I.; Black, N.; Lindon, H.; Allkin, R.; Magill, R.E.; Nicolson, N. Counting counts: Revised estimates of numbers of accepted species of flowering plants, seed plants, vascular plants and land plants with a review of other recent estimates. Phytotaxa 2016, 272, 82-88. [CrossRef]

129. Meshnick, S.R.; Dobson, M.J. The history of antimalarial drugs. In Antimalarial Chemotherapy; Springer: Berlin/Heidelberg, Germany, 2001; pp. 15-25.

130. Newman, D.J.; Cragg, G.M. Drugs and drug candidates from marine sources: An assessment of the current "state of play". Planta Med. 2016, 82, 775-789. [CrossRef]

131. Reader, J.; van der Watt, M.E.; Taylor, D.; Le Manach, C.; Mittal, N.; Ottilie, S.; Theron, A.; Moyo, P.; Erlank, E.; Nardini, L. Multistage and transmission-blocking targeted antimalarials discovered from the open-source MMV Pandemic Response Box. bioRxiv 2020. [CrossRef]

132. Abraham, M.; Gagaring, K.; Martino, M.L.; Vanaerschot, M.; Plouffe, D.M.; Calla, J.; Godinez-Macias, K.P.; Du, A.Y.; Wree, M.; Antonova-Koch, Y. Probing the Open Global Health Chemical Diversity Library for Multistage-Active Starting Points for Next-Generation Antimalarials. ACS Infect. Dis. 2020, 6, 613-628. [CrossRef]

133. Spangenberg, T.; Burrows, J.N.; Kowalczyk, P.; McDonald, S.; Wells, T.N.; Willis, P. The open access malaria box: A drug discovery catalyst for neglected diseases. PLoS ONE 2013, 8, e62906. [CrossRef]

134. Bapela, M.J.; Heyman, H.; Senejoux, F.; Meyer, J.M. 1H NMR-based metabolomics of antimalarial plant species traditionally used by Vha-Venda people in Limpopo Province, South Africa and isolation of antiplasmodial compounds. J. Ethnopharmacol. 2019, 228, 148-155. [CrossRef]

135. Heyman, H.M.; Senejoux, F.; Seibert, I.; Klimkait, T.; Maharaj, V.J.; Meyer, J.J.M. Identification of anti-HIV active dicaffeoylquinic-and tricaffeoylquinic acids in Helichrysum populifolium by NMR-based metabolomic guided fractionation. Fitoterapia 2015, 103, 155-164. [CrossRef] [PubMed]

136. Kellogg, J.J.; Todd, D.A.; Egan, J.M.; Raja, H.A.; Oberlies, N.H.; Kvalheim, O.M.; Cech, N.B. Biochemometrics for natural products research: Comparison of data analysis approaches and application to identification of bioactive compounds. J. Nat. Prod. 2016, 79, 376-386. [CrossRef] [PubMed]

137. Vidal, V.; Potterat, O.; Louvel Sv Hamy Fo Mojarrab, M.; Sanglier, J.-J.; Klimkait, T.; Hamburger, M. Library-based discovery and characterization of daphnane diterpenes as potent and selective HIV inhibitors in Daphne gnidium. J. Nat. Prod. 2011, 75, 414-419. [CrossRef] [PubMed]

138. Thornburg, C.C.; Britt, J.R.; Evans, J.R.; Akee, R.K.; Whitt, J.A.; Trinh, S.K.; Harris, M.J.; Thompson, J.R.; Ewing, T.L.; Shipley, S.M. NCI program for natural product discovery: A publicly-accessible library of natural product fractions for high-throughput screening. ACS Chem. Biol. 2018, 13, 2484-2497. [CrossRef]

(C) 2020 by the authors. Licensee MDPI, Basel, Switzerland. This article is an open access article distributed under the terms and conditions of the Creative Commons Attribution (CC BY) license (http://creativecommons.org/licenses/by/4.0/). 